\title{
Effect of Motivation and Job Satisfaction on Teacher Performance in Private Madrasah Aliyah in Maros Regency
}

\author{
Fadliyana Nur, Ulfiani Rahman, Musdalifa \\ Pascasarjana UIN Alauddin Makssar \\ Email: fadliyanan@gmail.com
}

(Received: March 16-2019; revised: March 29-2019; published: May 31-2019)

\begin{abstract}
This study aims to determine and analyze the effect of motivation and job satisfaction on teacher performance at the Maros Regency Private Madrasah Aliyah. The type of research used was quantitative with the ex post facto method and data management techniques were analyzed descriptively and inferentially. The instrument is a questionnaire that has been tested for validity and reliability. The sample in this study were 116 private Madrasah Aliyah teachers in Maros Regency whose research was conducted in December 2018 - February 2019. The results of the study revealed that the effect of motivation and job satisfaction had a significant effect on the performance of Private Madrasahs in Maros Regency. That is, work motivation must be increased so that it can affect teacher performance. If job satisfaction is increased, the motivation of teacher work must be increased. Together, motivation and job satisfaction have a significant effect on teacher performance in maros district.
\end{abstract}

Keywords: Motivation; Job Satisfaction; Teacher Performance.

\section{INTRODUCTION}

One of the most important factors to be considered and optimized by organizations or educational institutions in achieving their goals is the factor of human resources (HR) for organizations, especially in the field of education (Niswaty, Rusbiati, Jamaluddin, \& Salam, 2017; Saggaf, Salam, \& Rifka, 2017; Salam, Rosdiana, Suarlin, \& Akib, 2014). Educational institutions are organizations that are highly dependent on the performance of their HR members.

School as an institution or educational institution is a means of carrying out learning services and educational processes. Thus, it can be said that schools are part of the components of educational organizations that aim to provide learning services (Sagala, 2007). In addition, schools are also seen as public organizations that require management from professional people. In carrying out school management, namely the work process by utilizing other people to achieve organizational goals efficiently (Siagian, 2002).

One of the important goals to improve human resources, in an educational institution is the management of human resources that treat people in accordance with applicable norms. Giving the right motivation will provide job satisfaction can improve teacher performance in educational institutions (Wijaya \& Suana, 2013). This is in line with the results of research conducted by Eros (2014) that teacher work motivation has a positive and significant effect on teacher performance. 
10 Jurnal Ilmiah Ilmu Administrasi Publik: Jurnal Pemikiran dan Penelitian Administrasi Publik
Volume 9 Number 1, January - June 2019. Page 9-18

Teacher job satisfaction in an educational institution is very important to note. Job satisfaction is the expectation of each teacher, but many factors cause job satisfaction not to be fulfilled in the implementation of teachers as teachers and educators. According to Ahmadiansah (2016) in his research shows that motivation and job satisfaction on teacher performance is significant with a significance of $0.003<0.05$. Value of 6.378 , with an effective contribution of $20.7 \%$.

George R. Terry in Suhartini (2013) argues that "motivation is a desire found in an individual person, which stimulates to take actions". Motivation can also be interpreted as trying so that someone can complete the work with enthusiasm because he wants to implement it (Terry, 2009). According to Siagian (2002) motivation is the driving force that causes a member of the organization to be willing and willing to mobilize abilities in shaping their skills and skills and time. Meanwhile, according to Malayu (2007) motivation is the provision of driving force that creates the willingness of someone to work, so that they want to work together, work effectively, and integrate with all the power and effort to achieve satisfaction in doing work.

Some of the above meanings can be concluded, that work motivation is something that can cause enthusiasm or encouragement to work individuals or groups on their work in order to achieve goals.

Giving motivation to teachers in educational institutions, according to Luthan (2008, 138), motivation has elements consisting of 3 parts, namely: needs, encouragement (drives), and gifts (intencive). While the factors that influence motivation according to (Suhartini, 2013) the factors that influence motivation are divided into two, namely: (1) Internal factors that originate from within the individual, consisting of: individual perceptions of oneself, self-esteem and achievement expectations, needs and job satisfaction. (2) External factors originating from outside the individual, consisting of: the type and nature of the employee, the work group where the individual joins, the environmental situation in general and the system of compensation received.

In giving motivation, a leader needs to pay attention to the need to explore a number of things, so that the goals can be achieved as expected, namely understanding the behavior of subordinates, acting and behaving realistically, the level of needs of each person is different, being able to use expertise, and giving motivation (Sutrisno, 2009).

In addition to giving motivation, job satisfaction is a very important factor to consider in educational institutions. The term "satisfaction" refers to the general attitude of an individual to one's work with a high level of job satisfaction showing a positive attitude towards work (Sutrisno, 2009). Job satisfaction reflects a person's feelings for his job. This appears in the positive attitude of employees towards work and everything that is faced in the work environment (Sunyoto, 2012). Robbins (1994) defines job satisfaction as a general attitude of an individual and the amount they believe they should receive. Job satisfaction is determined by several factors namely work that is mentally challenging, and the suitability of personality with work. Whereas according to Handoko (2003) job satisfaction is a pleasant or unpleasant emotional state related to how one views their work.

Indicators of job satisfaction according to Celluci and David in Luthans (2001) are: satisfaction with salary, satisfaction with promotion, satisfaction with work colleagues, the job itself and supervisor. The fulfillment of job satisfaction indicators will provide job satisfaction. 
According to Robins (2003: 149) the impact of job satisfaction is five, namely: the impact on productivity, the impact on stakeholder satisfaction, the impact on life satisfaction, the impact on absenteeism and the impact on turnover.

In the scope of education, the notion of performance is a result achieved by the educator or teacher at his job in a certain period of time and can be measured. The term performance comes from the word job performance or actual performance as a result of work or work performance (Karatepe, 2013; Pitafi, Kanwal, Ali, Khan, \& Waqas Ameen, 2018; Sui, Smith, Fagan, Rollo, \& Prapavessis, 2019). Whereas according to Saggaf et al. (2018) the concept of performance stands for work energy kinetics which in English is performance. Performance is the output produced by functions or individuals on a particular job or profession.

Based on the definition stated earlier, it can be concluded that performance is the result of work achieved by a person or group of people in the organization, in accordance with their respective authorities and responsibilities in an effort to legally achieve the objectives of the organization concerned, not violating the law and according to moral and aesthetic.

According to Riordan in (Berardini, 2010) indicators in performance are: timeliness, quantity and quality. If these indicators are met, it will have an impact on performance, namely: achievement of targets, loyalty, training and development, promotion, encouraging people to behave positively or improve their actions that are below performance standards and provide a solid basis for policy making for improvement organization.

Given the importance of motivation, job satisfaction and teacher performance, this article presents the results of the study on the effect of motivation and job satisfaction on teacher performance at the Maros Regency Private Madrasah.

\section{METHOD}

This type of research is quantitative with the ex post facto method, which uses descriptive statistical data analysis and inferential analysis to determine the effect of motivation and job satisfaction on teacher performance in Private Madrasah Aliyah in Maros Regency. This research was conducted at Private Aliyah Madrasas in Maros Regency, the time of the research was carried out in December 2018 - February 2019. The approach used was the Psychology approach, the data collection method was obtained by questionnaire and documentation, while the research instruments were selected tools and used by researchers in their activities, in collecting data so that the activities become systematic and easy to understand, and management techniques and data analysis are obtained through questionnaires filled out by respondents or private Madrasah Aliyah teachers then processed and analyzed using data processing techniques to produce a conclusion on the problem under study.

\section{RESULT AND DISCUSSION}

The characteristics of the respondents are profiles of the objects of research that give an interpretation of the study of the effect of motivation and job satisfaction on teacher performance in Private Madrasah Aliyah in Maros Regency. consisting of 116 people from 5 schools that became the object of research. Based on the distribution of respondents according to gender gender shows that teachers in Private Aliyah Madrasas in Maros Regency have 45 
12 |Jurnal Ilmiah Ilmu Administrasi Publik: Jurnal Pemikiran dan Penelitian Administrasi Publik

Volume 9 Number 1, January - June 2019. Page 9-18

responses $(38.8 \%)$ with male sex and at most 71 respondents $(61.2 \%)$ with female gender. This can show that the entire task of the teacher educates, guides, directs and teaches training and evaluating carried out by all teachers both men and women in educational institutions. While the distribution of age respondents showed that the age of respondents in Private Aliyah Madrasah in Maros district were 39 respondents or (33.6\%) aged 21-30 years who were the most aged of respondents and 35 respondents $(30.2 \%)$ with ages $31-40$ year, as many as 38 or $(32.8 \%)$ respondents aged 41-50 years and as many as 4 people or (3.4\%). This shows that the age of each respondent was 116 different for each Aliyah Madrasah in Maros district. Judging from the level of education shows that the education strata for private Madrasah Aliyah teachers in Maros Regency, the education level of S1 respondents was 107 people or $(92.2 \%)$, then in the education process the $\mathrm{S} 2$ level showed that there were still 9 respondents $(7.8 \%)$. This shows that teachers are very concerned about the level of education in order to improve their duties and responsibilities as teachers in Maros Regency. Based on the distribution of respondents, it was shown that the teacher respondents in Maros Regency had a work period of up to five years, namely a group of $1-5$ years working period of 33 people or $(28.4 \%)$. Then groups of 6-10 years working period were 36 people or $(31.0 \%)$. The $11-15$ year group was 35 people or $(30.2 \%)$. Groups> 16 also as many as 12 people or $(10.3 \%)$. This shows that the working period of each respondent is 116 people differently in Private Madrasahs in Maros Regency.

The study was conducted in 2018 and obtained data according to the number of variables to be examined, namely by using two independent variables and one dependent variable. The two independent variables in each study were motivation (X1), occupational power (X2) while the non-independent variable was the teacher's performance in Private Madrasah Aliyah in Maros Regency which was symbolized as (Y).

Based on the results of research conducted on teachers in Private Aliyah Madrasas in Maros Regency which numbered 116 related motivations, researchers can collect data through a scale filled by teachers who are then given a score on each item. Based on the work motivation category after processing, it was obtained that the work motivation (X1) of teachers in Private Aliyah Madrasas in Maros Regency obtained through the instrument showed that the mean value was 25.47 , and the median value was 25.00 with a standard deviation of 1.810 variant values of 3.277 and range 9 and minimum 21, maximum value 30 and sum value 2954 .

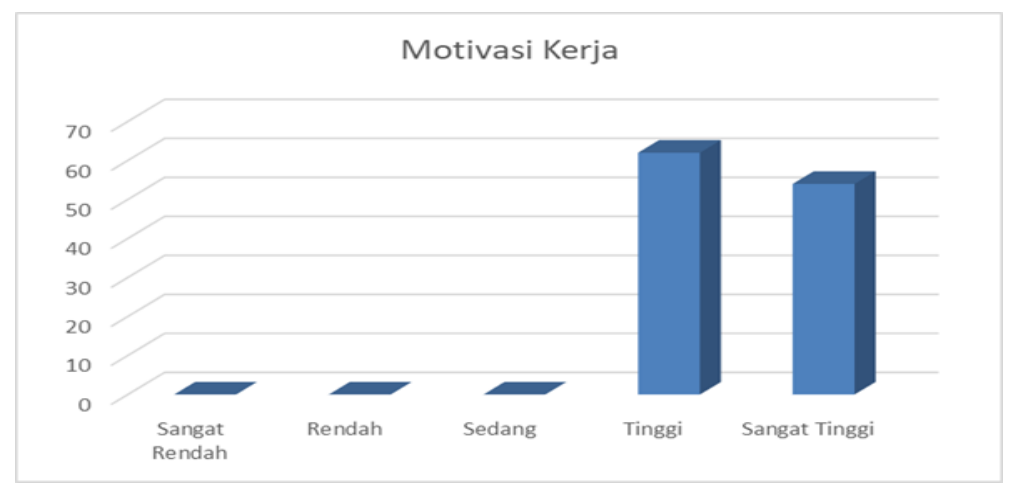

Source: Data after processing 2018 


\section{Figure 1 Work Motivation Indicators}

Based on the bar diagram above there are frequency values 0 in the very low, low, and medium categories. While the value of frequency 62 is in the high category and the frequency value of 54 is in the very high category. If it is associated with the average work motivation of the teacher then it can be concluded that the Private Madrasah Aliyah in Maros Regency. It is in the high category of 62 .

The description above explains that job satisfaction (X2) of teachers in Private Aliyah Madrasas in Maros Regency obtained through the instrument shows that the mean value is 24.78 , and the median value is 24.00 with a standard deviation of 1.630 variant value of 2.657 while range 8 and minimum 22, value maximum 30 and sum value 2875 .

Teacher performance ( $\mathrm{Y}$ ) in private Madrasah Aliyah in Maros Regency. which is obtained through the instrument shows that the mean value is 25.34 , and the median value is 25.00 with the standard deviation of 1.929 the variance value is 3.721 and the range is 10 and minimum is 20 , the maximum value is 30 and the value of sum is 2939 .

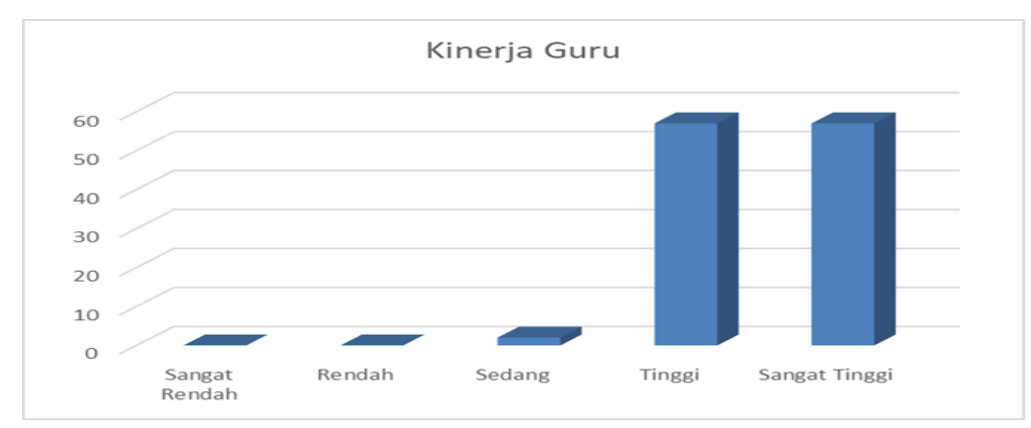

Source: Data after processing 2018

Figure 2 Teacher performance indicators

Based on the bar diagram above there are frequency values 0 in the very low, low, and frequency 2 categories in the medium category. While the frequency value of 57 is in the high category and the frequency value 57 is in the very high category. If it is associated with the average teacher performance in Private Madrasah Aliyah in Maros Regency. it can be concluded that the performance of teachers in the high and very high categories has the same frequency of 57.

Inferential statistical analysis and testing are carried out using SPSS for Windows, as follows: Based on multiple regression analysis the motivation variable (X1) is 0.615 with a positive sign indicating that if the motivation of teachers in Private Aliayh Madrasas in Maros Regency is increased according to their duties and responsibilities as teachers then it can improve teacher performance positively marked on Private Aliayh Madrasas in Maros Regency with a probability value $=0,000$ or less than 0.05 . Thus it can be used to carry out hypothesis analysis testing. The results of the analysis using multiple linear regression to test the truth of 
14 | Jurnal Ilmiah Ilmu Administrasi Publik: Jurnal Pemikiran dan Penelitian Administrasi Publik Volume 9 Number 1, January - June 2019. Page 9-18

this research hypothesis, the statistical analysis model used is multiple regression with the help of the SPSS statistical program that is in accordance with the concept of this research.

Table 1

Summary of the Results of Multiple Regression Analysis

\begin{tabular}{|l|l|l|l|}
\hline Independent Variables & $\begin{array}{l}\text { Regression } \\
\text { Coefficient }\end{array}$ & $\begin{array}{l}\text { T test } \\
\text { Statistics }\end{array}$ & Significance (prob) \\
\hline Motivation $\left(\mathrm{X}_{1}\right)$ & 0,450 & 5.163 & .000 \\
\hline Job satisfaction $\left(\mathrm{X}_{2}\right)$ & 0,385 & 3.977 & .000 \\
\hline Correlation coefficient $(\mathrm{R})$ & 0,644 & \\
Coefficient of Determination $\left(\mathrm{R}^{2}\right)$ & 0,415 & \\
$\mathrm{~F}_{\text {hitung }}$ & 40,111 & \\
Sig. Simultan & 0,000 & \\
Konstanta $\left(\mathrm{b}_{0}\right)$ & 4,333 & \\
\hline
\end{tabular}

Source: Data after processing 2018

Based on table 1 shows that simultaneously multiple regression of this research model are:

$Y=4,333+0,450\left(X_{1}\right)+0,385\left(X_{2}\right)$

Based on the results of statistical analysis through the SPSS program, the two independent variables namely motivation (X1) and job satisfaction (X2) together have a positive and significant effect on teacher performance in Private Madrasah Aliyah in Maros Regency (Y) which can be calculated through $\mathrm{f}$ arithmetic $=40,111$ and propability (sig) $=0,000=<\alpha=0.05$.

While the contribution or contribution of the influence of the two independent variables is relatively large, namely motivation (X1) and job satisfaction (X2) on teacher performance in Private Madrasah Aliyah in Maros Regency (Y). Shown through the value of determination index (R2) 0.415 or $41.5 \%$ variation in performance against 0.585 or $5.85 \%$ performance of teachers in Private Madrasah Aliyah in Kabupaten Maros (Y). Determined by other factors not included in other studies. Thus the two variables can be used as predictions to improve performance predictions in Private Aliyah Madrasas in Maros Regency (Y).

$F$ test to determine the magnitude of the influence of independent variables on the dependent variable together. Accepted in this case the research hypothesis is:

Ho: there is no significant effect of the independent variable on the dependent variable (performance).

Ha: there is a significant effect of the independent variable on the dependent variable (performance) 


\section{Table 2}

\section{Summary of Anova for Significance Tests}

\section{Model Summary ${ }^{\mathrm{b}}$}

\begin{tabular}{|c|c|c|c|c|c|}
\hline Model & $\begin{array}{ll}\text { Sum } & \text { of } \\
\text { Squares }\end{array}$ & Df & $\begin{array}{l}\text { Mean } \\
\text { Square }\end{array}$ & $\mathrm{F}$ & Sig. \\
\hline $\begin{array}{ll} & \begin{array}{l}\text { Regression } \\
\text { Residual } \\
\text { Total }\end{array} \\
\end{array}$ & $\begin{array}{l}177.651 \\
250.237 \\
427.888\end{array}$ & $\begin{array}{l}2 \\
113 \\
115\end{array}$ & $\begin{array}{l}88.825 \\
2.214\end{array}$ & 40.111 & $.000^{\mathrm{b}}$ \\
\hline
\end{tabular}

a. Dependent Variable: Teacher Performance

b. Predictors: (Constant), Job Satisfaction, Work Motivation

Source: Data after processing 2018

Table 2 shows that the calculated $\mathrm{F}$ value is $40,111 \mathrm{~F}$ tables for $\mathrm{N}$ (1) 2 and $\mathrm{N}$ (2) obtained values of 3.08. Based on the results of the calculation, it means that the calculated $\mathrm{F}$ value is greater than the value of the $F$ table (40.111> 3.08) with the statistical $F$ value of probability (significance) is $0,000<\alpha=0.05$. So that the decision taken by Ho is accepted. This means that all independent variables namely motivation and job satisfaction together significantly influence the dependent variable of teacher performance in Private Madrasah Aliyah in Maros Regency (Y).

The $\mathrm{T}$ test is individually all the regression coefficients that are respondents whose purpose is to determine the magnitude of the influence of each independent variable on the dependent variable. The $\mathrm{T}$ test is carried out on the freedom of degrees $(\mathrm{N}-\mathrm{K}-1)$ where the number of respondents and $\mathrm{K}$ are the number of variables. For the level of confidence used is $90 \%$ or $\alpha=0.05$

From this study, the results show that the correlation $(\mathrm{R})=0.644$ shows that there is a strong relationship between work motivation, job satisfaction and teacher performance in Private Madrasah Aliyah in Maros Regency. So that if motivation and job satisfaction are increased, it will have an impact on increasing teacher performance in Private Madrasah Aliyah in Maros Regency.

Likewise the results of the coefficient of determination are 0.415 . This means that the contribution of variables of motivation and job satisfaction jointly influence the performance of teachers in Private Aliyah Madrasas in Maros Regency. $41.5 \%$ and the rest of $5.85 \%$ is determined by other factors, so it still needs to find variables that cannot be identified in this study, so that the next researchers must explore more deeply so that variables can be found that can influence the performance of teachers in Madrasahs. Private Aliyah in Maros Regency.

Based on the results of the study it was found that work motivation had a positive and significant influence on teachers in Private Madrasah Aliyah in Maros Regency. This means that the higher the work motivation of the teacher, the higher the performance of the teacher concerned, and vice versa the lower the work motivation of the teacher in carrying out his duties, the lower the performance of the teacher concerned. assuming other factors that influence remain constant with a regression coefficient of $0.450, \mathrm{t}$ count of 5.163 and probability of $0.000<0.05$. 
16 | Jurnal Ilmiah Ilmu Administrasi Publik: Jurnal Pemikiran dan Penelitian Administrasi Publik
Volume 9 Number 1, January - June 2019. Page 9-18

If every teacher in a Private Aliyah Madrasah in Maros Regency is able to increase work motivation in him and apply in educational institutions and for himself as a teacher in order to improve the quality of education that is educating, teaching, guiding, directing, training, evaluating and evaluating students in education early childhood formal education, primary and secondary education. So improving performance both individually and educational institutions where teachers work can also be improved.

The implementation of the results of this study is that in order to improve teacher performance, efforts should still be made to increase teacher motivation in private Madrasah Aliyah in Maros Regency. Based on the results of work motivation research (X1) and job satisfaction (X2), it has a positive effect on teacher performance in Private Madrasah Aliyah in Maros Regency. This is shown in the results table of multiple regression analysis that motivation ((X1) with a regression coefficient of 0.450 and job satisfaction (X2) with a regression coefficient of 0.384 .

From the regression equation shows that motivation (X1) with a regression coefficient of 0.450 is the most dominant variable that influences teacher performance in Private Madrasah Aliyah in Maros Regency.

\section{CONCLUSION}

Based on the results of data analysis and discussion that has been described in the previous section, it can be stated some conclusions from the results of this study (1) work motivation has a significant effect on teacher performance in Private Madrasah Aliyah in Maros Regency. (2) Job satisfaction has a significant effect on Teacher performance in Private Aliyah Madrasas in Maros Regency. (3) the dominant work motivation variable has the most influence on teacher performance in Private Madrasah Aliyah in Maros Regency. In carrying out its duties educating, teaching, guiding, directing, training, evaluating and evaluating.

\section{REFERENCES}

Ahmadiansah, R. (2016). Pengaruh motivasi kerja dan kepuasan kerja terhadap kinerja guru SMK Muhammadiyah Salatiga. INJECT (Interdisciplinary Journal of Communication), $1(2), 223-236$.

Berardini, V. (2010). Discovering performance indicators in late medieval sermons. Medieval Sermon Studies, 54(1), 75-86.

Eros, E. (2014). Pengaruh motivasi dan kedisiplinan kerja guru terhadap kinerja guru di smp negeri kecamatan brebes kabupaten brebes jawa tengah. Jurnal Administrasi Publik Dan Birokrasi, 1(1).

Handoko, T. H. (2003). Manajemen edisi 2. Yogyakarta: BPFE.

Karatepe, O. M. (2013). High-performance work practices and hotel employee performance: The mediation of work engagement. International Journal of Hospitality Management, 32, 132-140. https://doi.org/https://doi.org/10.1016/j.ijhm.2012.05.003 
Malayu, H. (2007). Manajemen sumber daya manusia. Bumi Aksara. Jakarta.

Niswaty, R., Rusbiati, S., Jamaluddin, J., \& Salam, R. (2017). The Influence of Teacher's Reinforcement for Students Motivation. International Conference on Education, Science, Art and Technology, 148-152.

Pitafi, A. H., Kanwal, S., Ali, A., Khan, A. N., \& Waqas Ameen, M. (2018). Moderating roles of IT competency and work cooperation on employee work performance in an ESM environment. Technology in Society, 55, 199-208. https://doi.org/https://doi.org/10.1016/j.techsoc.2018.08.002

Robbins, S. P. (1994). Teori organisasi: struktur, desain dan aplikasi. Jakarta: Arcan.

Sagala, S. (2007). Manajemen strategik dalam peningkatan mutu pendidikan. Bandung: Alfabeta.

Saggaf, M. S., Aras, M., Akib, H., Salam, R., Baharuddin, A., \& Kasmita, M. (2018). The Quality Analysis of Academic Services Based on Importance Performance Analysis (IPA).

Saggaf, M. S., Salam, R., \& Rifka, R. (2017). The Effect of Classroom Management on Student Learning Outcomes. International Conference on Education, Science, Art and Technology, 98-102.

Salam, R., Rosdiana, Suarlin, \& Akib, H. (2014). The Impact Of Policy on Region Expansion to Office Administrative Services in Barombong Subdistrict of Gowa District. International Conference on Mathematics, Sciences, Technology, Education and Their Applications, 1(1), 505. State University of Makassar.

Siagian, S. P. (2002). Kiat meningkatkan produktivitas kerja. Jakarta: Rineka Cipta.

Suhartini, E. (2013). Motivasi, Kepuasan Kerja dan Kinerja. Samata: Alauddin University Press.

Sui, W., Smith, S. T., Fagan, M. J., Rollo, S., \& Prapavessis, H. (2019). The effects of sedentary behaviour interventions on work-related productivity and performance outcomes in real and simulated office work: A systematic review. Applied Ergonomics, 75, 27-73. https://doi.org/https://doi.org/10.1016/j.apergo.2018.09.002

Sunyoto, D. (2012). Teori, Kuesioner, dan Analisis Data Sumber Daya Manusia (Praktik Penelitian). Yogyakarta: CAPS (Center for Academic Publishing Service).

Sutrisno, E. (2009). Manajemen Sumber Daya Manusia Edisi pertama. Jakarta: Kencana Prenada Media Group.

Terry, G. R. (2009). Prinsip-Prinsip Manajemen cetakan 10. Jakarta: PT. Bumi Aksara.

Wijaya, I., \& Suana, I. W. (2013). Pengaruh Penempatan Dan Pengalaman Terhadap Kepuasan Dan Kinerja Karyawan. E-Jurnal Manajemen Universitas Udayana, 2(10), 1311-1332. 
18 | Jurnal Ilmiah Ilmu Administrasi Publik: Jurnal Pemikiran dan Penelitian Administrasi Publik Volume 9 Number 1, January - June 2019. Page 9-18 